\title{
Correlation of plasma levels of digoxin in cardiac patients with dose and measures of renal function
}

\begin{abstract}
There is a well-established relationship between plasma concentrations of digoxin (PDC's) and therapeutic and toxic effects. The readily obtainable parameters, namely, dose, body weight, age, sex, and creatinine clearance or serum creatinine concentration, might be expected to allow accurate prediction of $P D C^{\prime}$ 's. We have now found that these parameters do not allow accurate prediction of PDC's in the individual patient, based on data collected in a panel of cardiac patients. Serial measurements of PDC's are therefore necessary in individual patients taking digoxin. These conclusions are based on the following results. Forty-eight equilibrium state PDC's were measured in 25 patients (13 males, 12 females) both under ward conditions $(N=11)$ and in the Clinical Research Center $(N=27)$. Multiple linear regression accounted for only $34 \%$ of the variance of the $P D C$ 's. Individual variables accounted for the following percentages of the total variance of the PDC's: dose, $14.3 \%$; serum creatinine concentration, $10.9 \%$; reciprocal of body weight, $3.1 \%$; reciprocal of urinary excretion rate of creatinine, $0.9 \%$; age, $0.7 \%$, and height, $0.02 \%$. Practically, the digoxin level $(\mathrm{ng} / \mathrm{ml})$ is equal to one fifth of the product of the $\mu \mathrm{g} / \mathrm{kg}$ dose of digoxin and the serum creatinine concentration in $\mathrm{mg} / 100 \mathrm{ml}$. Such a correlation accounts for only about one third of the variance of the PDC's; hence predicted levels have a wide confidence interval.
\end{abstract}

John G. Wagner, Ph.D., James D. Yates, M.D., Park W. Willis III, M.D., Ermelinda Sakmar, and Roger G. Stoll, Ph.D. Ann Arbor, Mich.

College of Pharmacy and Staff Member of the Upjohn Center for Clinical Pharmacology, Section of Cardiology, Department of Internal Medicine, and College of Pharmacy, The University of Michigan

Partly supported by a grant-in-aid from the American Heart Association and the Michigan Heart Association, partly by Public Health Service Grant No. FR-42, University of Michigan Clinical Research Center, and partly by Public Health Service Grant No. 5-P11-GM 15559, Upjohn Center for Clinical Pharmacology, The University of Michigan.

Received for publication Sept. 11, 1973.

Accepted for publication Sept. 23, 1973.

Reprint requests to: John G. Wagner, Ph.D., Upjohn Center for Clinical Pharmacology, The University of Michigan, Ann Arbor, Mich. 48104.
Empirical digitalizing and maintenance doses of digoxin have been relied upon traditionally. ${ }^{1}$ However, widespread use of this drug has resulted in rates of toxicity that approach $20 \%$ of hospitalized patients taking the drug. ${ }^{18}$ High mortality figures have also been reported..$^{15}$ There may be a significant incidence of "underdigitalization" as well. ${ }^{2}$ The elevation of digoxin 
Table I. Data collected in study

\begin{tabular}{|c|c|c|c|c|c|c|c|c|c|}
\hline Patient & Diagnosis & Sex & $\begin{array}{c}\text { Body } \\
\text { weight } \\
(k g) \\
\end{array}$ & $\begin{array}{l}\text { Height } \\
(\mathrm{cm})\end{array}$ & $\begin{array}{l}\text { Age } \\
(y r)\end{array}$ & $\begin{array}{c}\text { Dose } \\
(\text { ug/day })\end{array}$ & $\begin{array}{c}\text { Urinary } \\
\text { creatinine } \\
(\mathrm{gm} / 24 \mathrm{hr})\end{array}$ & $\begin{array}{c}\text { Serum } \\
\text { creatinine } \\
(\mathrm{mg} / \\
100 \mathrm{ml})\end{array}$ & $\begin{array}{l}\text { Plasma } \\
\text { digoxin } \\
(n g / m l)\end{array}$ \\
\hline $1^{*}$ & RHD $\neq$ & $\mathrm{M}$ & $\begin{array}{l}71.6 \\
71.2 \\
66.7 \\
66.4\end{array}$ & 173 & 68 & $\begin{array}{l}125 \\
125 \\
125 \\
125\end{array}$ & $\begin{array}{l}1.23 \\
1.26 \\
1.30 \\
1.40\end{array}$ & $\begin{array}{l}1.52 \\
1.55 \\
0.913 \\
0.940\end{array}$ & $\begin{array}{l}0.62 \\
0.68 \\
0.52 \\
0.50\end{array}$ \\
\hline $2^{*}$ & ASHD $\S$ & $\mathbf{M}$ & $\begin{array}{l}94.5 \\
95.0\end{array}$ & 146 & 52 & $\begin{array}{l}250 \\
250\end{array}$ & $\begin{array}{l}1.22 \\
1.62\end{array}$ & $\begin{array}{l}1.20 \\
1.05\end{array}$ & $\begin{array}{l}0.76 \\
0.65\end{array}$ \\
\hline $3^{*}$ & RHD $\ddagger$ & F & $\begin{array}{l}49.0 \\
49.6\end{array}$ & 160 & 52 & $\begin{array}{l}250 \\
250\end{array}$ & $\begin{array}{l}1.25 \\
0.83\end{array}$ & $\begin{array}{l}0.86 \\
0.81\end{array}$ & $\begin{array}{l}0.74 \\
0.75\end{array}$ \\
\hline $4^{*}$ & $\mathrm{PPH} \|$ & F & $\begin{array}{l}45.5 \\
45.8\end{array}$ & 152 & 22 & $\begin{array}{l}250 \\
250\end{array}$ & $\begin{array}{l}1.03 \\
1.07\end{array}$ & $\begin{array}{l}0.975 \\
0.975\end{array}$ & $\begin{array}{l}0.98 \\
0.71\end{array}$ \\
\hline $5^{*}$ & RHD $\ddagger$ & $\mathbf{M}$ & $\begin{array}{l}74.6 \\
72.9\end{array}$ & 182 & 50 & $\begin{array}{l}250 \\
250\end{array}$ & $\begin{array}{l}1.38 \\
2.14\end{array}$ & $\begin{array}{l}1.48 \\
1.25\end{array}$ & $\begin{array}{l}0.77 \\
0.81\end{array}$ \\
\hline $6^{*}$ & ASHDS & $\mathbf{M}$ & $\begin{array}{l}77.9 \\
77.7\end{array}$ & 178 & 66 & $\begin{array}{l}125 \\
125\end{array}$ & $\begin{array}{l}1.55 \\
1.46\end{array}$ & $\begin{array}{l}1.36 \\
1.43\end{array}$ & $\begin{array}{l}0.25 \\
0.28\end{array}$ \\
\hline $7^{*}$ & RHD & $\mathbf{M}$ & $\begin{array}{l}59.4 \\
59.4\end{array}$ & 182 & 39 & $\begin{array}{l}250 \\
250\end{array}$ & $\begin{array}{l}2.1 \\
1.33\end{array}$ & $\begin{array}{l}0.854 \\
0.953\end{array}$ & $\begin{array}{l}0.125 \\
0.15\end{array}$ \\
\hline $8^{\circ}$ & $\mathrm{C} \mathbb{T}$ & F & $\begin{array}{l}55.2 \\
53.7\end{array}$ & 165 & 24 & $\begin{array}{l}250 \\
250\end{array}$ & $\begin{array}{l}0.747 \\
0.8\end{array}$ & $\begin{array}{l}1.06 \\
1.10\end{array}$ & $\begin{array}{l}0.98 \\
1.17\end{array}$ \\
\hline $9^{*}$ & RHD & $\mathbf{M}$ & $\begin{array}{l}76.8 \\
76.7\end{array}$ & 168 & 68 & $\begin{array}{l}125 \\
125\end{array}$ & $\begin{array}{l}1.6 \\
1.36\end{array}$ & $\begin{array}{l}1.37 \\
1.25\end{array}$ & $\begin{array}{l}0.24 \\
0.35\end{array}$ \\
\hline $10^{*}$ & CHD\# & F & $\begin{array}{l}45.0 \\
45.1\end{array}$ & 152 & 53 & $\begin{array}{l}125 \\
125\end{array}$ & $\begin{array}{l}0.951 \\
0.954\end{array}$ & $\begin{array}{l}1.32 \\
1.37\end{array}$ & $\begin{array}{l}0.92 \\
1.16\end{array}$ \\
\hline $11^{*}$ & RHD & $\mathbf{M}$ & $\begin{array}{l}70.2 \\
69.5\end{array}$ & 180 & 61 & $\begin{array}{l}250 \\
250\end{array}$ & $\begin{array}{l}1.49 \\
1.48\end{array}$ & $\begin{array}{l}1.25 \\
1.32\end{array}$ & $\begin{array}{l}0.425 \\
0.45\end{array}$ \\
\hline $\begin{array}{l}\text { Patient } \\
\text { †Patient } \\
\text { † Rheum } \\
\text { \$Arterio } \\
\text { ॥Primar } \\
\text { \Cardio } \\
\text { \#Conge }\end{array}$ & $\begin{array}{l}\text { studied in } 0 \\
\text { studied in } \\
\text { atic heart dis } \\
\text { sclerotic hear } \\
\text { y pulmonary } \\
\text { myopathy. } \\
\text { nital heart di }\end{array}$ & $\begin{array}{l}\text { se. } \\
\text { lisease. } \\
\text { pertens }\end{array}$ & rrch Center & & 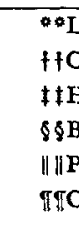 & $\begin{array}{l}\text { us erythema } \\
\text { cific aortic st } \\
\text { ertensive he } \\
\text { terial endoca } \\
\text { myositis. } \\
\text { onic pericard }\end{array}$ & $\begin{array}{l}\text { tosus. } \\
\text { enosis. } \\
\text { art disease. } \\
\text { rditis. } \\
\text { lial effusion. }\end{array}$ & & \\
\hline
\end{tabular}

plasma concentrations and slowing of urinary excretion of the drug in patients with impaired renal function and in anephric patients compared with those with normal renal function have been clearly shown., 5, 7 The usefulness of an educational program in digitalis therapy in reducing intoxication has also been clearly shown. ${ }^{16}$

The mathematical analysis of digitalis kinetics in patients with normal and impaired renal function ${ }^{7,8}$ and a study of factors affecting endogenous creatinine clearance $^{9,10}$ (which is used as a measure of renal function) have led to an improved method of digoxin therapy ${ }^{11}$ and computer- assisted digoxin therapy. ${ }^{12,}{ }^{17}$ Jelliffe, Buell, and $\mathrm{Kalaba}^{12}$ reported good correlation $(\mathbf{r}=0.86)$ between computed body glycoside levels and measured serum digoxin concentration in 70 patients; however, despite the high correlation coefficient there was considerable scatter of points and a large amount of unexplained variance. Recently, Peck and associates ${ }^{17}$ reported a randomized, prospective clinical trial comparing performance of physicians in their use of digoxin with and without computer assistance. Their results indicated that only $17.6 \%$ of the variance of measured serum digoxin concentrations was accounted for 
Table I. Cont'd

\begin{tabular}{|c|c|c|c|c|c|c|c|c|c|}
\hline Patient & Diagnosis & Sex & $\begin{array}{c}\text { Body } \\
\text { weight } \\
(\mathrm{kg})\end{array}$ & $\begin{array}{c}\text { Height } \\
(\mathrm{cm})\end{array}$ & $\begin{array}{l}\text { Age } \\
(y r)\end{array}$ & $\begin{array}{c}\text { Dose } \\
(\mu g / d a y)\end{array}$ & $\begin{array}{c}\text { Urinary } \\
\text { creatinine } \\
(\mathrm{gm} / 24 \mathrm{hr})\end{array}$ & $\begin{array}{c}\text { Serum } \\
\text { creatinine } \\
(\mathrm{mg} / 100 \\
\mathrm{ml})\end{array}$ & $\begin{array}{l}\text { Plasma } \\
\text { digoxin } \\
(n g / m l)\end{array}$ \\
\hline $12 *$ & ASHD\$ & $\mathbf{M}$ & $\begin{array}{l}65.4 \\
65.3\end{array}$ & 173 & 56 & $\begin{array}{l}125 \\
125\end{array}$ & $\begin{array}{l}1.03 \\
0.826\end{array}$ & $\begin{array}{l}1.27 \\
0.810\end{array}$ & $\begin{array}{l}0.50 \\
0.70\end{array}$ \\
\hline $13^{*}$ & ASHD\$ & $\mathrm{F}$ & $\begin{array}{l}62.5 \\
62.1\end{array}$ & 166 & 68 & $\begin{array}{l}125 \\
125\end{array}$ & $\begin{array}{l}1.02 \\
0.932\end{array}$ & $\begin{array}{l}0.77 \mathrm{I} \\
0.865\end{array}$ & $\begin{array}{l}0.33 \\
0.34\end{array}$ \\
\hline $14^{*}$ & $\mathrm{LE}^{*}$ & $\mathrm{~F}$ & $\begin{array}{l}86.5 \\
85.2\end{array}$ & 164 & 49 & $\begin{array}{l}250 \\
250\end{array}$ & $\begin{array}{l}1.62 \\
1.33\end{array}$ & $\begin{array}{l}0.905 \\
2.81\end{array}$ & $\begin{array}{l}0.37 \\
0.45\end{array}$ \\
\hline $15^{\circ}$ & ASHD $\$$ & M & $\begin{array}{l}76.5 \\
75.7\end{array}$ & 175 & 80 & $\begin{array}{l}250 \\
250\end{array}$ & $\begin{array}{l}1.33 \\
1.33\end{array}$ & $\begin{array}{l}2.87 \\
1.86\end{array}$ & $\begin{array}{l}0.87 \\
1.40\end{array}$ \\
\hline $16^{*}$ & CAStA & M & 84.0 & 181 & 57 & 250 & 1.57 & 1.58 & 0.65 \\
\hline $17^{*}$ & CAStP & M & $\begin{array}{l}61.4 \\
61.2\end{array}$ & 182 & 62 & $\begin{array}{l}250 \\
250\end{array}$ & $\begin{array}{l}1.54 \\
1.03\end{array}$ & $\begin{array}{l}1.54 \\
1.22\end{array}$ & $\begin{array}{l}2.49 \\
0.41\end{array}$ \\
\hline $18^{*}$ & ASHD\$ & $\mathbf{F}$ & $\begin{array}{l}50.7 \\
50.4\end{array}$ & 151 & 76 & $\begin{array}{l}125 \\
125\end{array}$ & $\begin{array}{l}0.862 \\
0.661\end{array}$ & $\begin{array}{l}0.964 \\
0.994\end{array}$ & $\begin{array}{l}0.33 \\
0.32\end{array}$ \\
\hline 197 & ASHD $\$$ & $\mathrm{~F}$ & $\begin{array}{l}56.9 \\
56.9\end{array}$ & 157 & 58 & $\begin{array}{l}250 \\
250\end{array}$ & $\begin{array}{l}0.78 \\
0.80\end{array}$ & $\begin{array}{l}1.0 \\
0.7\end{array}$ & $\begin{array}{l}1.0 \\
1.39\end{array}$ \\
\hline $20 t$ & HHD龺幸 & $F$ & 53.5 & 166 & 44 & 250 & 0.97 & 2.0 & 1.67 \\
\hline $21 t$ & RHD & M & $\begin{array}{l}84.7 \\
84.3\end{array}$ & 174 & 39 & $\begin{array}{l}250 \\
250\end{array}$ & $\begin{array}{l}1.2 \\
1.0\end{array}$ & $\begin{array}{l}1.1 \\
1.4\end{array}$ & $\begin{array}{l}0.97 \\
1.30\end{array}$ \\
\hline $22 \uparrow$ & $\begin{array}{l}\text { ASHD } \$ \\
\quad \mathrm{PM}\|\|\end{array}$ & $\mathrm{F}$ & $\begin{array}{l}78.0 \\
78.0\end{array}$ & 160 & 61 & $\begin{array}{l}125 \\
125\end{array}$ & $\begin{array}{l}0.59 \\
0.68\end{array}$ & $\begin{array}{l}1.3 \\
1.3\end{array}$ & $\begin{array}{l}0.43 \\
0.58\end{array}$ \\
\hline $23 t$ & $B E \S \S$ & $\mathbf{F}$ & $\begin{array}{l}52.3 \\
51.7\end{array}$ & 168 & 33 & $\begin{array}{l}125 \\
125\end{array}$ & $\begin{array}{l}0.9 \\
0.7\end{array}$ & $\begin{array}{l}0.9 \\
1.0\end{array}$ & $\begin{array}{l}0.70 \\
0.71\end{array}$ \\
\hline $\begin{array}{l}24 \uparrow \\
25 \uparrow\end{array}$ & $\begin{array}{l}\text { ASHD } \\
\text { CPE } \Uparrow \Uparrow\end{array}$ & $\begin{array}{l}\mathrm{M} \\
\mathrm{F}\end{array}$ & $\begin{array}{l}65.3 \\
63.5\end{array}$ & $\begin{array}{l}168 \\
163\end{array}$ & $\begin{array}{l}71 \\
44\end{array}$ & $\begin{array}{l}250 \\
250\end{array}$ & $\begin{array}{l}1.1 \\
1.1\end{array}$ & $\begin{array}{l}1.6 \\
0.8\end{array}$ & $\begin{array}{l}2.79 \\
1.18\end{array}$ \\
\hline
\end{tabular}

by the computer-predicted serum digoxin concentrations and only $2 \%$ of the variance of the measured serum digoxin concentrations was accounted for by the physicianpredicted serum digoxin concentrations.

We report here a study in which plasma digoxin concentrations, measured in cardiac patients, were correlated with all readily measured parameters such as serum creatinine concentration, urinary excretion rate of creatinine, dose of digoxin, body weight, age, and height-all at once, in various combinations, and individually. The purpose was to estimate how accurately one could predict plasma digoxin concentration in a given patient from information on all the above parameters-when the correlation data were based on a panel of patients.

\section{Materials and methods}

The subjects were 25 patients, 13 males and 12 females. Nineteen were studied on two consecutive days. One was studied for two consecutive days at two different times. Six were studied during only one day. Eighteen were studied under closely controlled conditions in the Clinical Research Center of University Hospital. Seven were studied on the wards of the same hospital. All patients had been receiving either $0.125 \mathrm{mg}$ or $0.25 \mathrm{mg}$ of digoxin (Lanoxin) orally in tablet form once daily for at least 6 days and usually much longer.

When patients were studied in the clinical Research Center they were admitted about 10 A.M. on day 1 , and a quantitative urine collection was made from 10 A.M. until the same time on day 2. They had already received their daily dose of digoxin about 7 A.M. on day 1. At 7 A.M. on day 2 blood was drawn; an aliquot of this blood was used for a serum creatinine determination performed in the laboratories of the Clinical Research Center and the remain- 
Table II. Multiple linear regression results $(N=48)$

\begin{tabular}{|c|c|c|c|c|}
\hline$X=$ Independent variable & $\begin{array}{l}\text { Regression } \\
\text { coefficient }\end{array}$ & $\begin{array}{c}t \text { value } \\
(d f=41)\end{array}$ & $\begin{array}{c}\text { Correlation } \\
\text { coefficient }(r)\end{array}$ & $100 r^{2}$ \\
\hline Dose $(\mu \mathrm{g})$ & $0.372 \times 10^{-2}$ & $2.747^{\circ}$ & 0.378 & 14.3 \\
\hline Serum creatinine $(\mathrm{mg} / 100 \mathrm{ml})$ & 0.440 & $2.383 \dagger$ & 0.330 & 10.9 \\
\hline Reciprocal of body weight $\left(\mathrm{kg}^{-1}\right)$ & $0.411 \times 10^{2}$ & $1.649 \ddagger$ & 0.176 & 3.1 \\
\hline $\begin{array}{l}\text { Reciprocal of urinary excretion } \\
\text { rate of creatinine }(24 \mathrm{br} / \mathrm{gm})\end{array}$ & 0.375 & $1231 t$ & 0.096 & 0.9 \\
\hline Age $(y r)$ & $0.217 \times 10^{-2}$ & $0.361+$ & -0.081 & 0.7 \\
\hline Height $(\mathrm{cm})$ & $-0.317 \times 10^{-5}$ & $0.000 \ddagger$ & -0.015 & 0.02 \\
\hline
\end{tabular}

der of the blood was treated with citrate, centrifuged as rapidly as possible, and kept in the frozen state until the digoxin concentration of the plasma was determined by the radioimmunoassay method of Stoll and associates. ${ }^{20}$ The 24 hour urine sample was also assayed for creatinine in the same laboratory. Those patients studied on 2 consecutive days received their usual dose of digoxin about 7 A.M. on day 2 , immediately after taking the blood sample. Urine was collected again from 10 A.M. on day 2 to 10 A.M. on day 3 , and a second blood sample was taken at 7 A.M. on day 3 for serum creatinine and digoxin determinations.

When patients were studied on the wards, dosing with digoxin was at 8 A.M., urine was collected from 8 A.M. on day 1 to 8 A.M. on day 2 , and blood for serum creatinine and digoxin concentrations was taken 8 hours after dosing (about 4 P.M.). Four of the 7 patients studied on the wards were studied for 2 consecutive days. The serum and urine of ward patients were analyzed for creatinine in the Clinical Pathology Laboratory of University Hospital. All digoxin determinations were made by the same laboratory technician in the laboratory of the senior author.

Sex, body weight, height, age, daily dose of digoxin, and diagnosis of each patient are given in Table $\mathbf{I}$.

The consistency of our data with that reported by others was checked in two dif- ferent ways. First, the $95 \%$ confidence intervals of average plasma digoxin concentrations (PDC) for patients taking both 0.125 and $0.25 \mathrm{mg}$ of digoxin per day in our study were compared with the line values predicted from a plot of average serum or plasma digoxin concentrations against daily dose of digoxin based on data available in the literature. ${ }^{13,19}$ Second, the slopes and intercepts of log-log plots of creatinine clearance $\left(\mathrm{ml} / \mathrm{min} . / 1.73 \mathrm{~m}^{2}\right.$ body surface area) against serum creatinine concentration $(\mathrm{mg} / 100 \mathrm{ml})$ from the 48 sets of data in our study were compared with similar slopes and intercepts available in the literature. ${ }^{6,22}$

\section{Results}

Values of urinary excretion rate of creatinine, serum creatinine concentration, and PDC for each day each patient was studied are shown in Table I. There are 48 sets of data for the 48 patient days. These results were analyzed in several ways.

Multiple linear regression. A multiple linear regression was performed with a suitable program on the IBM $360 / 65$ digital computer. The dependent variable was PDC. The independent variables were dose of digoxin, serum creatinine concentration, reciprocal of body weight, ${ }^{2}$ reciprocal of urinary excretion rate of creatinine, ${ }^{*}$ age, and height. Results are shown in Table II.

- See Appendix. 
Table III. Simple linear regressions $(N=48)$ each performed independently

\begin{tabular}{|c|c|c|c|c|}
\hline$y=$ Dependent variable & $x=$ Independent variable & $\begin{array}{c}\text { Correlation } \\
\text { coefficient } \\
(r)\end{array}$ & $\begin{array}{l}\text { Significance } \\
\quad \text { level }\end{array}$ & $100 r^{2}(\%)$ \\
\hline Body surface area $\left(\mathrm{m}^{2}\right)$ & Body weight $(\mathrm{kg})$ & 0.919 & $\mathrm{p} \ll 0.001$ & 84.5 \\
\hline $\begin{array}{l}\text { Excretion rate of creatinine } \\
\quad(\mathrm{mg} / 24 \mathrm{hr})\end{array}$ & Height $(\mathrm{cm})$ & 0.516 & $\mathrm{p}<0.001$ & 26.6 \\
\hline $\begin{array}{l}\log \text { ( Excretion rate of creati- } \\
\text { nine }[\mathrm{mg} / 24 \mathrm{hr}])\end{array}$ & $\log$ (Height, $\mathrm{cm})$ & 0.501 & $\mathrm{p}<0.001$ & 25.1 \\
\hline $\begin{array}{l}\text { Excretion rate of creatinine } \\
\qquad(\mathrm{mg} / 24 \mathrm{hr})\end{array}$ & Body surface area $\left(\mathrm{m}^{2}\right)$ & 0.461 & $\mathrm{p} \simeq 0.001$ & 21.2 \\
\hline $\begin{array}{l}\text { Excretion rate of creatinine } \\
(\mathrm{mg} / 24 \mathrm{hr})\end{array}$ & Body weight (kg) & 0.458 & $\mathrm{p} \simeq 0.001$ & 21.0 \\
\hline Body weight $(\mathrm{kg})$ & Height $(\mathrm{cm})$ & 0.254 & $0.10>p>0.05$ & 6.5 \\
\hline $\begin{array}{l}\text { Plasma digoxin concentration } \\
\qquad(\mathrm{ng} / \mathrm{ml})\end{array}$ & Dose of digoxin ( $\mu \mathrm{g} /$ day $)$ & 0.395 & $0.01>p>0.001$ & 15.6 \\
\hline $\begin{array}{l}\text { Plasma digoxin concentration } \\
(\mathrm{ng} / \mathrm{ml})\end{array}$ & $\begin{array}{l}\text { Serum creatinine concentration } \\
(\mathrm{mg} / 100 \mathrm{ml})\end{array}$ & 0.326 & $0.05>p>0.02$ & 10.6 \\
\hline $\begin{array}{l}\text { Plasma digoxin concentration } \\
(\mathrm{ng} / \mathrm{ml})\end{array}$ & $\begin{array}{l}\text { Reciprocal of body weight } \\
(1 / \mathrm{kg})\end{array}$ & 0.152 & $\mathrm{p}>0.10$ & 2.3 \\
\hline $\begin{array}{l}\text { Plasma digoxin concentration } \\
(\mathrm{ng} / \mathrm{ml})\end{array}$ & Reciprocal of age in years & 0.099 & $\mathrm{p}>0.10$ & 1.0 \\
\hline $\begin{array}{l}\text { Plasma digoxin concentration } \\
\quad(\mathrm{ng} / \mathrm{ml})\end{array}$ & $\begin{array}{l}\text { Reciprocal of excretion rate of } \\
\text { creatinine in } \mathrm{gm} / 24 \mathrm{hr}\end{array}$ & 0.080 & $\mathrm{p}>0.10$ & 0.6 \\
\hline $\begin{array}{l}\text { Plasma digoxin concentration } \\
(\mathrm{ng} / \mathrm{ml})\end{array}$ & Reciprocal of height in $\mathrm{cm}$ & 0.041 & $\mathrm{p}>0.10$ & 0.2 \\
\hline
\end{tabular}

A multiple correlation coefficient between one variable and a set of other variables is defined to be the maximum correlation between the one variable and a linear combination of the other variables. ${ }^{14}$ Table II indicates that the multiple correlation coefficient $(r)$ in this case was 0.586 . The value of $100 \mathrm{r}^{2}$ gives the percentage of the total variance of the dependent variable, which is accounted for by the linear combination of the other variables. In this case the value of $100 \mathrm{r}^{2}$ was 34.3 ; hence, only $34.4 \%$ of the total variance of the PDC's was accounted for by the 6 independent variables. Consequently, about two thirds of the variance of the measured PDC's is not accounted for by the dose of digoxin, serum creatinine concentration, reciprocal of body weight, reciprocal of urinary excretion rate of creatinine, age, and height associated with each digoxin concentration. The results in Table II indicate that the dose of digoxin alone accounted for only $14.3 \%$ of the variance of the PDC's, and the serum creatinine concentration ac- counted for only $10.9 \%$ of the variance of the PDC's. The other four variables accounted for only minor percentages of the total variance of the PDC's.

Simple linear regressions. In Tables III and IV are shown the results of simple linear regressions-all but two of which correlated individually only one variable against another variable. Not surprisingly, ${ }^{22}$ the adult patient panel gave a high correlation coefficient $(r=0.919)$ for the correlation of body surface area with body weight (Table III). Surprisingly, the correlation of excretion rate of creatinine with height gave a reasonably high correlation coefficient $(\mathrm{r}=0.516)$. Because of the high correlation between body surface area and body weight, the correlation of excretion rate of creatinine with body weight $(\mathrm{r}=0.458)$ had a similar " $\mathrm{r}$ " value to the correlation of excretion rate of creatinine with body surface area $(r=0.461)$. This suggests that for adults, correcting creatinine clearance to that of a $70 \mathrm{~kg}$ man would be essentially as good as correcting 
Table IV. Statistics of regression lines for various correlations

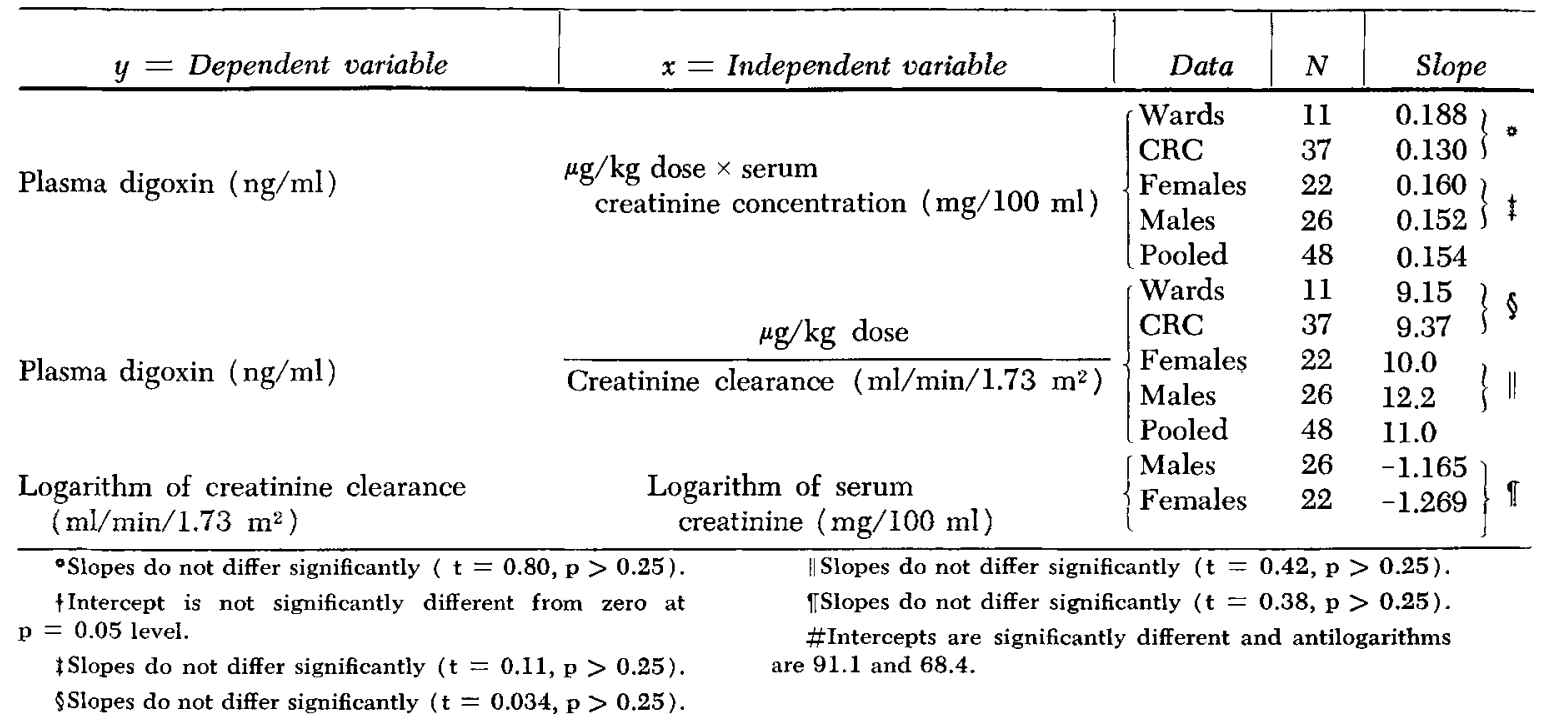

to $1.73 \mathrm{~m}^{2}$ body surface area as is usually done. Data of Wagner ${ }^{22}$ support this.

The individual correlation results shown at the bottom of Table III confirmed the results obtained in the multiple linear regression. Only the correlation of PDC with dose of digoxin and of PDC with serum creatinine concentration accounted for any appreciable percentage of the variance of the PDC's, but the $100 \mathbf{r}^{2}$ values were only $15.6 \%$ and $10.6 \%$, respectively. Owing to the preceding results, the two correlations shown at the top of Table IV were performed. First, the PDC was correlated with the produce of the $\mu \mathrm{g} / \mathrm{kg}$ dose of digoxin and the serum creatinine concentration. ${ }^{3}$ Second, the PDC was correlated with the quotient of the $\mu \mathrm{g} / \mathrm{kg}$ dose of digoxin and the creatinine clearance."

To justify the pooling of all the data, similar correlations were performed with the ward data alone ( $\mathrm{N}=11$ ), the Clinical Research Center data alone $(\mathrm{N}=37)$, data from females only $(N=22)$, and data from males only $(N=26)$. In each of these correlations the intercept was not significantly different from zero. For each correlation the slope for ward data was

"See Appendix. not significantly different from the slope for Clinical Fesearch Center data; the slope for females was not significantly different from the slope for males.

Fig. 1 shows a plot of the PDC against the product of the $\mu \mathrm{g} / \mathrm{kg}$ dose of digoxin and the serum creatinine concentration for the pooled data. The $r$ value is 0.562 ; hence $100 \mathrm{r}^{2}=31.6$. Thus the product of the $\mu \mathrm{g} /$ $\mathrm{kg}$ and the serum creatinine concentration accounts for $31.6 \%$ of the variance of the PDC's. The latter is only slightly less than the $34.3 \%$ accounted for by 6 variables in the multiple linear regression. Since the intercept of 0.17 in Fig. 1 is not significantly different from zero, and theory would suggest that the line should go through the 0,0 point, the least squares line forced through the origin was calculated; this line has the equation $y=0.19 \mathrm{x}$ rather than the equation $\mathrm{y}=0.17+0.154 \mathrm{x}$ for the line shown in Fig. 1. If one rounds off the 0.19 to 0.2 , then a practical guide is that the plasma digoxin concentration in $\mathrm{ng} / \mathrm{ml}$ is given by one fifth of the product of the $\mu \mathrm{g} / \mathrm{kg}$ dose of digoxin and the serum creatinine concentration in $\mathrm{mg} / 100$ $\mathrm{ml}$. However, with the wide scatter evident in Fig. 1, the predictability of such a formula for the individual patient is ob- 


\begin{tabular}{|c|c|c|}
\hline Intercept & $\begin{array}{c}\text { Correlation } \\
\text { coefficient }\end{array}$ & Prob. level \\
\hline $0.36 \uparrow$ & 0.593 & $0.10<\mathrm{p}<0.05$ \\
\hline $0.16 \uparrow$ & 0.577 & $\mathrm{p}<0.001$ \\
\hline $0.18 \uparrow$ & 0.732 & $\mathrm{p}<0.001$ \\
\hline $0.14 \uparrow$ & 0.505 & $0.01>p>0.001$ \\
\hline $0.17 \nmid$ & 0.562 & $p<0.001$ \\
\hline $0.53 t$ & 0.346 & $\mathrm{p}>0.10$ \\
\hline $0.22 \uparrow$ & 0.538 & $p<0.001$ \\
\hline $0.21 †$ & 0.649 & $0.01>\mathrm{p}>0.001$ \\
\hline $0.18 \uparrow$ & 0.515 & $0.01>\mathrm{p}>0.001$ \\
\hline $0.21 \uparrow$ & 0.543 & $\mathrm{p}<0.001$ \\
\hline 1.835 & -0.856 & $\mathrm{p}<0.001$ \\
\hline 1.9592 & -0.754 & $\mathrm{p}<0.001$ \\
\hline
\end{tabular}

viously very poor. In other words, the confidence interval of such an estimate is very wide.

Comparison of our results with those of others. Fig. 2 is a plot of average serum or plasma digoxin concentration (y) against the dose of digoxin in $\mathrm{mg} /$ day $(\mathrm{x})$. The least squares line based only on the 6 points from the literature ${ }^{13,19}$ (not shown on the graph) is $\mathrm{y}=0.17+3.02 \mathrm{x}$. The regression values of $y$ corresponding to 0.125 and $0.25 \mathrm{mg}$ digoxin/day are 0.55 and $0.93 \mathrm{ng} / \mathrm{ml}$, respectively. From the data in Table $I$ the average PDC corresponding to $0.125 \mathrm{mg} /$ day was $0.52 \mathrm{ng} / \mathrm{ml}$ and the $95 \%$ confidence interval (CI) of the average is $0.52 \pm 0.11(0.41$ to 0.64$)$ for the 20 values. Similarly the average PDC corresponding to $0.25 \mathrm{mg} /$ day was $0.94 \mathrm{ng} / \mathrm{ml}$ and the $95 \% \mathrm{CI}$ of the average is $0.95 \pm 0.24,(0.70$ to 1.18$)$ for the 28 values. Thus the $95 \%$ CI's of the PDC's in our study for 0.125 and $0.25 \mathrm{mg} /$ day doses included the regression value of digoxin concentrations based on work in two other laboratories. In fact, the values of 0.55 and 0.52 and of 0.93 and 0.94 are amazingly similar. This indicates that the average digoxin levels obtained in our study agree very well with those obtained in different panels of patients and in different laboratories when the dose of digoxin is taken into consideration.

On the basis of the preceding our data were pooled with the literature values, and the least squares regression line was calculated from all 8 points shown in Fig. 2. This line had the equation: $y=0.10+3.16$ $\mathrm{x}(\mathrm{r}=0.970)$. Thus $94 \%$ of the variance of the average PDC's is accounted for by the differences in daily doses of digoxin. The intercept of 0.10 was not significantly different from zero. Also, theory indicates that the digoxin level should equal zero when the dose is zero. Hence the least squares line forced through the origin was calculated; this line has the equation: $y=$ $3.4 \mathrm{x}$. This is the line drawn through the points in Fig. 2. Thus, the average PDC's of panels of cardiac patients is well estimated by simply multiplying the daily dose of digoxin (expressed as mg/day) by 3.4 . The bars in Fig. 2 mark off \pm 1 S.D. The $95 \%$ of CI of an individual patient's PDC would be more than 1.96 times as long as these bars, since the student $t$ value has an asymptote of 1.96. Hence, although the graph and equations in Fig. 2 are useful for predicting average PDC's of panels of cardiac patients, they are of little or no use for predicting the PDC of an individual patient.

Effersøe ${ }^{i}$ was the first to show that the logarithm of the endogenous 24 hour creatinine clearance was linearly related to the logarithm of the serum creatinine concentration over a broad range, and that the slope of the line was greater than the value of unity expected for a simple reciprocal relationship between clearance and serum concentration. The intercepts of such plots are different for males and females, and this is most probably due to the differences in ratio of muscle mass/ body weight for the two sexes. Wagner ${ }^{22}$ supported the results of Effersøe by showing that two other independent sets of data obeyed the same relationship. The last entry in Table IV of the Appendix shows the values of the slopes and intercepts of such log-log plots for the male and female data of the present study. These slopes and intercepts for males and females in the present study were not significantly 


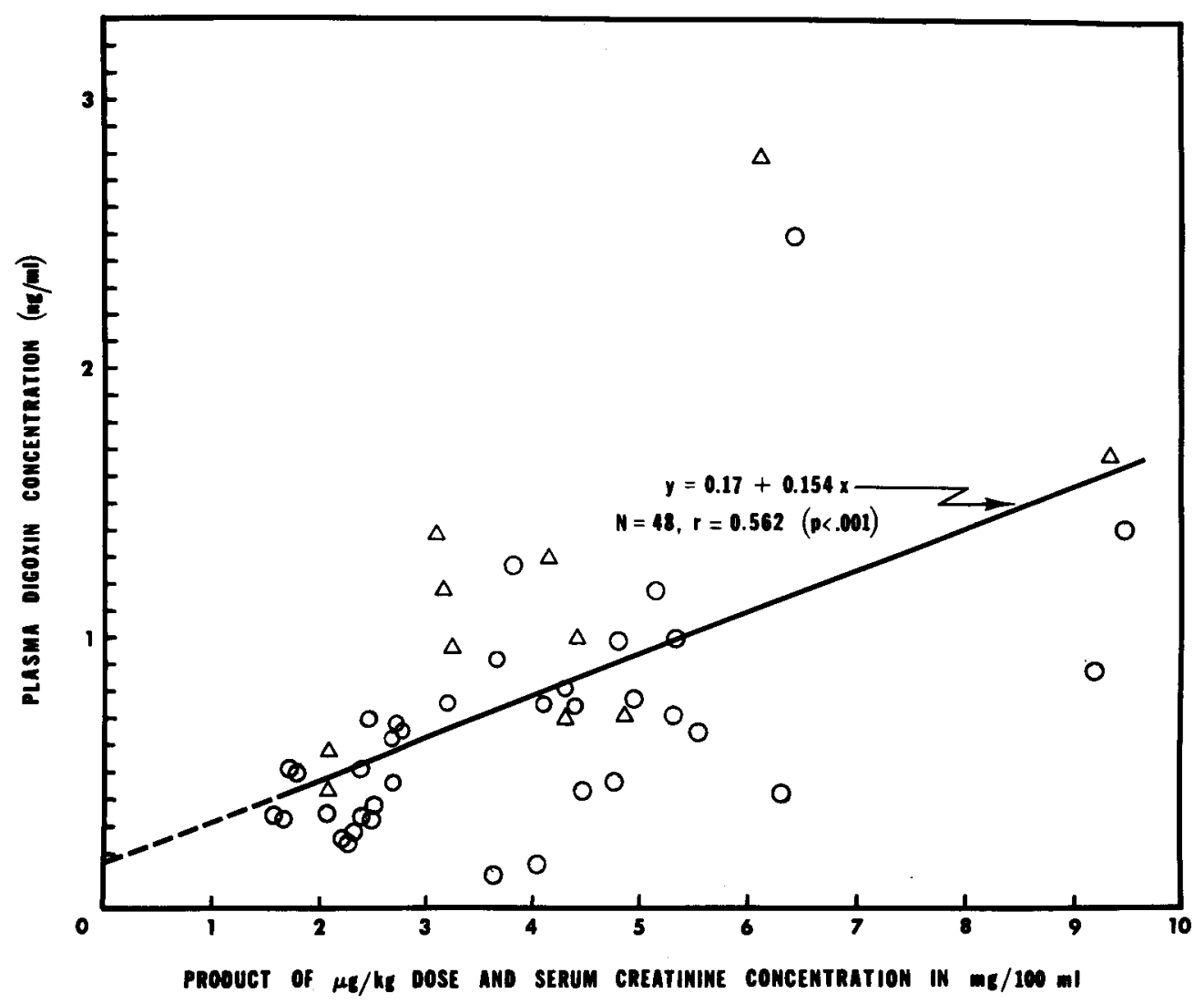

Fig. 1. A plot of plasma digoxin concentration against the product of the $\mu \mathrm{g} / \mathrm{kg}$ dose of digoxin and the serum creatinine concentration based on the 48 sets of data in Table I. Key: $O$, Clinical Research Center $(N=37) ; \Delta$, Wards $(N=11)$. See also Table IV of the Appendix for additional information.

different from the corresponding values, calculated by Wagner, ${ }^{22}$ for 98 random female patients and 100 random male patients of the same hospital where the present study was performed. This indicates that the creatinine urinary excretion data and the serum creatinine concentration data collected in the present study were consistent with the data in the literature.

\section{Discussion}

Emphasis has been placed on per cent of variance of PDC's, which has been explained. It is enlightening to also consider the absolute amounts of explained and unexplained variance. Jelliffe and associates ${ }^{12}$ had a total variance of $2.062 \mathrm{ng}^{2} / \mathrm{ml}^{2}$; they explained about $74 \%$ of the variance, but were left with a variance of 0.538 that was unexplained. In the present report the total variance was $0.281 \mathrm{ng}^{2} / \mathrm{ml}^{2}$ (calculated from PDC's in the last column of Table I); of this $34.3 \%$ was explained (Table II), leaving a variance of 0.185 that was unexplained. Thus, the unexplained variance of Jelliffe, Buell, and Kalaba ${ }^{12}$ was considerably greater than the unexplained variance in this report, even though the correlation coefficient reported by Jelliffe and associates ${ }^{12}$ was higher than the one reported in Table II of this report.

The results of the present study agree with the results of the study of Peck and associates. ${ }^{17}$ They stated that input to their computer program consisted of the patient's sex, age, height, weight, history of digoxin use, a measure of renal function (serum creatinine, BUN, or measured creatinine clearance), and physician-specified objectives. Such objectives included the 


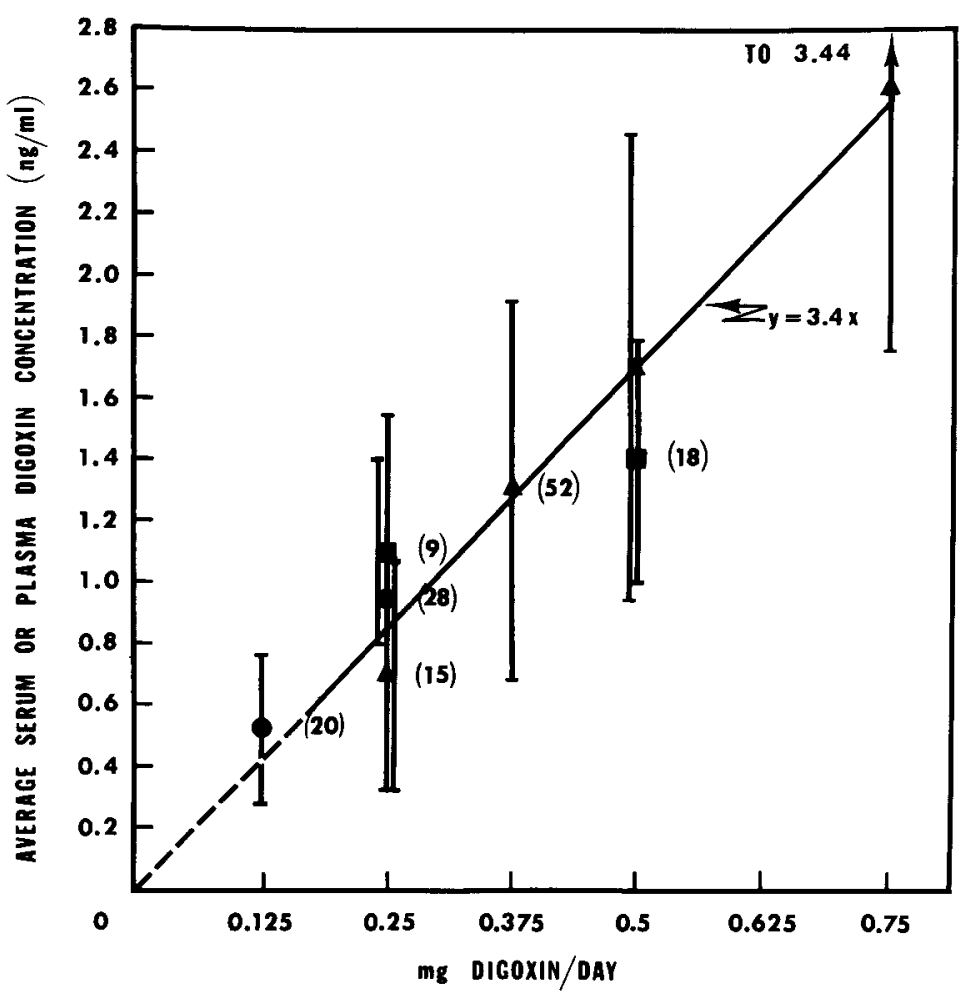

Fig. 2. A plot of average serum or plasma digoxin concentration against the daily dose of digoxin. Key: , Present study; $\mathbf{0}$, data of Smith, Butler, and Haber ${ }^{19}$; $\boldsymbol{\Delta}$, data of Larbig, Kochsiek, and Schrader. ${ }^{13}$ The line drawn through the points is the least squares line forced through the origin and has a slope of 3.4. The numbers of points upon which each average is based are shown in parentheses. The 0.5 and $0.75 \mathrm{mg} /$ day averages of Larbig and associates $^{13}$ are based on a total of 37 patients. The bars mark off \pm 1 S.D. on either side of the averages.

"desired" steady state serum concentration of digoxin (SDC), the time allowed to achieve steady state, and the time interval between maintenance doses. The output of the computer included a series of predicted serum digoxin concentrations at various past and future times. They also measured SDC and correlated measured SDC with computer-predicted SDC. They reported an $r$ value of 0.42 that was less than the $r$ value of 0.586 obtained in the present study in the multiple linear regression of PDC with 6 independent variables. Their $r$ value of 0.42 corresponds to a $100 \mathrm{r}^{2}$ value of $17.6 \%$. Hence only $17.6 \%$ of the variance of their measured SDC's was accounted for by the computer-predicted SDC's.

The present study has shown that the predictability of plasma or serum digoxin in an individual patient from dose of digoxin, body weight, serum creatinine concentration, urinary excretion rate of creatinine, age, and height - where the basic correlation data is from a panel of cardiac patients-is extremely low. We agree with the conclusion of Peck and associates ${ }^{17}$ that such results argue for serial measurement of PDC's in patients taking digoxin.

What causes the unexplained variance in the PDC's? The answer is purely speculative. Equation 2 in the Appendix suggests some of the factors that may be involved. The varying volume of distribution of digoxin, both interpatient and intrapatient, is undoubtedly a major cause of the unexplained variance of the PDC's. The tissue/plasma ratio of digoxin would be 
expected to vary widely from patient to patient, and this ratio will alter the apparent volume of distribution. Although some correction for variation in the rate constant of elimination of digoxin is made via creatinine clearance or serum creatinine concentration, there are still proportionality constants that vary from patient to patient as the plots reported by Wagner $^{22}$ illustrate. There may be variation in the fraction of each dose of digoxin that is absorbed, even when the digoxin is administered as one manufacturer's brand. This has not been studied, although wide variations have been shown ${ }^{2+}$ between different manufacturer's brands of digoxin.

All PDC's measured in our Clinical Research Center study were true minimum PDC's since they were measured 24 hours after dosing and just before the next dose. In the ward study the PDC's were measured about 8 hours after doses and hence were somewhat higher than the value at 24 hours would have been. This variation in sampling time, as has been done by other authors, ${ }^{19}$ contributes to some of the unexplained variance of the PDC's. Drug interactions also undoubtedly cause variation in the PDC's. All patients in our study were taking several other drugs as well as the digoxin. It has been repmi $d^{21}$ that other drugs can alter blood lev€ ' of digoxin. Intensive studies in individua. oatients would most probably elucidate, 'me of the sources of the unexplained $v$.riance of the PDC's.

We thank the members of the Clinical Research Center and the Heart Station staff of University Hospital, The University of Michigan, for assistance in carrying out this study.

\section{References}

1. Batterman, R. C., and DeGraff, A. C.: Comparative study in the use of the purified digitalis glycosides, digoxin, digitoxin and lanotoside $\mathrm{C}$, for the management of ambulatory patients with congestive heart failure, Am. Heart J. 34:663-673, 1947.

2. Beller, G. A., Smith, T. W., Abelmann, W. H., et al.: Digitalis intoxication: A prospective clinical study with serum level correlations, N. Engl. J. Med. 284:989-997, 1971.

3. Bloom, P. M., and Nelp, W. B.: Relationship of the excretion of tritiated digoxin to renal function, Am. J. Med. Sci. 251:133-144, 1966.

4. Diem, K., editor: Documenta Geigy Scientific Tables, ed. 6, New York, 1962, Geigy Pharmaceuticals, pp 178 and nomogram insert.

5. Doherty, J. E., Flanigan, W. J., Perkins, W. H., and Ackerman, G. L.: Studies with tritiated digoxin in anephric human subjects, Circulation 35:298-303, 1967.

6. Effers $\varnothing$, P.: Relationship between endogenous 24-hour creatinine clearance and serum creatinine concentration in patients with chronic renal disease, Acta Med. Scand. 156:429434, 1957.

7. Jelliffe, R. W.: A mathematical analysis of digitalis kinetics in patients with normal and reduced renal function, Math. Bio. Sci. 1:305325, 1967.

8. Jelliffe, R. W., Buell, J., Kalaba, R., Sridhar, R., and Rockwell, R.: A mathematical study of the metabolic conversion of digitoxin to digoxin in man, Math. Bio. Sci. 6:387-403, 1970.

9. Jelliffe, R. W., and Jelliffe, S. M.: Estimation of creatinine clearance from changing serumcreatinine levels, Lancet 2:710, 1971.

10. Jelliffe, R. W., and Jelliffe, S. M.: A computer program for estimation of creatinine clearance from unstable serum creatinine levels, age, sex, and weight, Math. Bio. Sci. 14:17-24, 1972.

11. Jelliffe, R. W.: An improved method of digoxin therapy, Ann. Intern. Med. 69:703-717, 1968.

12. Jelliffe, R. W., Buell, J., and Kalaba, R.: Reduction of digitalis toxicity by computerassisted glycoside dosage regimens, Ann. Intern. Med. 77:891-906, 1972.

13. Larbig, D., Kochsiek, K., and Schrader, Chr.: Klinische aspekte der radioimmunchemischen bestimmung der serum-digoxin konzentration, Dtsch. Med. Wochenschr. 97:139-145, 1972.

14. Lindgren, B. W.: Statistical theory, New York, 1963, The Macmillan Company, pp. 122.

15. Ogilvie, R. I., and Ruedy, J.: Adverse drug reactions during hospitalization, Can. Med. Assoc. J. 97:1450-1457, 1967.

16. Ogilvie, R. I., and Ruedy, J.: An educational program in digitalis therapy, J. A. M. A. 222: 50-55, 1972.

17. Peck, C., Sheiner, L., Martin, M., Combs, T., and Melmon, K. L.: Computer-assisted digoxin therapy, N. Engl. J. Med. 289:441446, 1973.

18. Rodensky, P. L., and Wasserman, F.: Observations on digitalis intoxication, Arch. Intern. Med. 108:171-188, 1961.

19. Smith, T. W., Butler, V. P., Jr., and Haber, E.: Determination of therapeutic and toxic 
serum digoxin concentrations by radioimmunoassay, N. Engl. J. Med. 281:1212-1216, 1969.

20. Stoll, R. G., Christensen, M. S., Sakmar, E., and Wagner, J. G.: The specificity of the digoxin radioimmunoassay procedure, Res. Commun. Chem. Pathol. Pharmacol. 4:503-510, 1972.

21. Thompson, W. G.: Altered absorption of digoxin in patients given propantheline and metoclopramide, Lancet, p. 772, April 7, 1973.

22. Wagner, J. G.: Biopharmaceutics and relevant pharmacokinetics, Hamilton, Ill., 1971, Drug Intelligence Publications, pp. 222-233.

23. Wagner, J. G., Northam, J. L., Alway, C. D., and Carpenter, O. S.: Blood levels of drug at the equilibrium state after multiple dosing, Nature 207:1301-1302, 1965.

24. Wagner, J. G., Christensen, M., Sakmar, E., Blair, D., Yates, J. D., Willis, P. W., III., Sedman, A. J., and Stoll, R, G.: Equivalence lack in digoxin plasma levels, J. A. M. A. 224:199-204, 1973.

\section{Appendix}

1. Creatinine clearance was calculated from data in Table I as follows:

$$
\begin{aligned}
\begin{aligned}
\text { Creatinine clearance } \\
\left(\mathrm{ml} / \mathrm{min} / 1.73 \mathrm{~m}^{2}\right)
\end{aligned} & =\frac{\text { Urinary creatinine }(\mathrm{gm} / 24 \mathrm{hr}) \times 10^{3} \times 1.73}{\text { Serum creatinine }(\mathrm{mg} / 100 \mathrm{ml}) \times 10^{-2} \times 1,440 \times \mathrm{S}\left(\mathrm{m}^{2}\right)} \\
& =\frac{\text { Urinary creatinine }(\mathrm{gm} / 24 \mathrm{hr})}{\text { Serum creatinine }(\mathrm{mg} / 100 \mathrm{ml}) \times \mathrm{S}\left(\mathrm{m}^{2}\right)} \times 120.1
\end{aligned}
$$

where $S$ is estimated body surface area from the DuBois-DuBois nomogram. ${ }^{4}$

2. Reasoning behind choice of independent variables in correlations.

Wagner and associates ${ }^{23}$ have shown that the average blood (serum or plasma) concentration of a drug $\overline{(\mathrm{C})}$ at the equilibrium state after multiple dosing is given by equation 2:

$$
\overline{\mathrm{C}}=\frac{\mathrm{FD}}{\mathrm{VK} \tau}
$$

In equation 2, $\mathrm{F}$ represents the fraction of the dose, $\mathrm{D}$, which is absorbed-hence FD represents the absorbed dose; $\mathrm{V}$ represents the apparent volume of distribution of the drug; $K$ represents the first order rate constant for over-all elimination from the body; and $\tau$ represents the dosage interval. Dividing the top and the bottom of the right-hand side of equation 2 by body weight ( $W$ ) gives equation 3 :

$$
\mathrm{C}=\frac{\mathrm{F}(\mathrm{D} / \mathrm{W})}{(\mathrm{V} / \mathrm{W}) \mathrm{K} \tau}
$$

In equation $3, \mathrm{D} / \mathrm{W}$ represents the $\mathrm{mg} / \mathrm{kg}$ or $\mu \mathrm{g} / \mathrm{kg}$ dose and $\mathrm{V} / \mathrm{W}$ represents the apparent volume of distribution in $\mathrm{L} / \mathrm{kg}$ or fraction of body weight, which is less variable than just the apparent volume of distribution in liters. ${ }^{22}$

Wagner $^{22}$ has summarized investigations showing that the rate constant $(K)$ for many drugs, including digoxin, is linearly related to the endogenous creatinine clearance. Also, endogenous creatinine clearance (uncorrected for surface area) is given by equation 4 :

$$
\begin{aligned}
\text { Creatinine clearance } & =\frac{\text { (Urinary flow rate) (urinary co icentration of creatinine) }}{\text { Serum concentration of creatinine }} \\
& =\frac{\text { Urinary excretion rate of creatinine }}{\text { Serum concentration of creatinine }}
\end{aligned}
$$

An equation analogous to equation 3 would give the minimum equilibrium state plasma concentration of digoxin measured in the present and literature studies. ${ }^{13,19}$ Such an equation would have to have an additional term added to equation 3.

Equations 3 and 4, however, indicate the rationale for choice of most of the independent variables in the various correlations reported. Equation 3 indicates PDC should be directly proportional to both dose of digoxin in mass units and in $\mu \mathrm{g} / \mathrm{kg}$ of the body weight. The equation also explains why reciprocal of body weight was an independent variable in the multiple linear regression. Since $K$ in equation 3 is directly proprtional to creatinine clearance, then equations 3 and 4 explain why the reciprocal of urinary excretion rate of creatinine was used as an independent variable in the multiple linear regression. From equations 3 and 4 and the $\mathrm{K}$ relationship, one would also expect PDC to be directly proprtional to both serum creatinine concentration and the product of the $\mu \mathrm{g} / \mathrm{kg}$ dose and serum creatinine concentration and also directly proportional to the quotient of the $\mu \mathrm{g} / \mathrm{kg}$ dose and the creatinine clearance. Age was introduced as an independent variable based on the report of Jelliffe and Jelliffe. ${ }^{9}$ Height was introduced as an independent variable because of the high correlation of excretion rate of creatinine with height (Table III). 